認定医症例報告

歯槽性の上顎前突に矯正および補綴治療にて審美回復を行った 1 症例

國安 宏哉

\title{
Maxillary Protrusion of Alveolar Patient with Orthodontic and Prosthodontic Treatment to Recover Esthetic: A Case Report
}

\author{
Hiroya Kuniyasu
}

抄 録

症例の概要：初診時 60 歳の男性で上顎前歯の審美障害を訴えて補綴，矯正科を受診した。低位咬合，歯 槽性の上顎前突と診断し，レベリングとリトラクション, 下顎部分床義歯と上顎連結冠の補綴治療を行い, 約 4 年経過するが経過は良好であった。

考察：矯正科，補経科それぞれ単独では治療に限界があり主訴を改善することが困難であると考えた。そ のためインターディシプリナリー・アプローチを行い，明確な治療方針を示すことができ，良好な結果が 得られていると思われる。

結論：上顎前突による審美障害に対して矯正，補綴によるインターディシプリナリー・アプローチを用い ることで審美的，機能的にも良好な結果が得られた。

和文キーワード

低位咬合，上顎前突，インターディシプリナリー・アプローチ

\section{ABSTRACT}

Patient: The patient was a 60-year-old male having a chief complaint of esthetic dissatisfaction with maxillary anterior teeth, and he consulted a physician of prosthodontics and orthodontics. We diagnosed the case as overclosure and maxillary protrusion of the dental alveolus character. We did prosthetic restoration by mandibular removable partial denture and maxillary connected crowns that used leveling, retraction of maxillary anterior teeth, and cast metal teeth. The passing of the patient was uneventful four years after treatment.

Discussion: In each orthodontics and prosthodontics alone, treatment had a limit, and I thought that I had difficulty in improving chief complaint. Therefore it seemed that if an interdisciplinary approach was done, a clear treatment plan could be shown and an excellent result obtained.

Conclusion: We used an interdisciplinary approach by orthodontics and prosthodontics for esthetic dissatisfaction by maxillary protrusion, and excellent results for esthetics and function were obtained.

\section{Key words}

overclosure, maxillary protrusion, interdisciplinary approach

くにやす歯科クリニック

Kuniyasu Dental Clinic

受付 : 2011 年 10 月 24 日/受理 : 2012 年 4 月 12 日

Received on October 24, 201 1/Accepted on April 12, 2012 


\section{I . 緒言}

上顎前歯唇側傾斜による審美障害を主訴とする症例で は，歯周疾患や臼歯部咬合崩壊を伴うことが多く見受け られる。このような症例では, 変位してしまった顎位の 修正や治療計画が重要になると思われる。特に，上顎前 突の唇側傾斜で生活歯を含む場合などは，補綴単独の治 療計画のみで十分な満足を得るのは難しいと思われる が，他科領域の治療を行うことで審美性の高い修復が実 現しやすい ${ }^{1)}$.

本症例は, 矯正, 補綴で協力しあい, インターデイシ プリナリー・アプローチを行い患者の満足を得た症例で ある。

\section{II．症例の概要}

患者：60 歳, 男性.

当科初診日：1999 年 8 月.

主訴：上顎前歯の審美不良.

医科既往歴：特記事項なし。

現病歴：1997 年頃から前歯の突き上げを自覚し, 北 海道医療大学歯学部附属病院保存科を受診してナイト ガードを製作し，歯周および歯内治療を受けていた。経 過は良好であったが，審美性の改善には至らず，1999 年 8 月 4 日に同附属病院保存科の紹介で矯正科および 補綴科を受診した（図 1 )。

現症：顔面は左右対称性で, 正貌は Square type, 側 貌は Neutro type. E-lineは上唇 $7 \mathrm{~mm}$, 下唇 4.5 $\mathrm{mm}$. 自力最大開口量 $60.3 \mathrm{~mm}$ で, 顎関節雑音, 咀嚼 筋の圧痛などの顎関節症状は認めなかった. (5) 4 (3) 2(1)(1)(2)にテテポラリーブリッジ, 765|4567 に部分床義歯, $4567, \overline{4}$ に全部鋳造冠，3に前装 鋳造冠が装着されていた。 6 に根面板が装着されてい た.

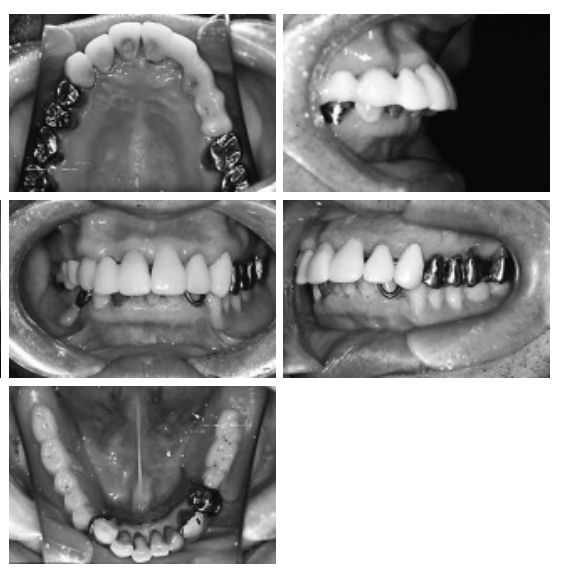

図 1 Intraoral views at initial visit of the department of prosthetic dentistry 補綴科初診時口腔内写真

咬合検査: オーバージェット右 $8.0 \mathrm{~mm}$, 左 7.0 $\mathrm{mm}$, オーバーバイト右 $4.5 \mathrm{~mm}$, 左 $4.5 \mathrm{~mm}$. 側方運 動時は, グループファンクションドオクルージョンであ る.

エックス線検査: 全顎的に水平的骨吸収像が認められ る. 骨格的に上顎前突は認められない $\left(2^{\circ} \leqq \mathrm{ANB} \leqq 4^{\circ}\right)$ が，歯槽性の上顎前突が認められる（図 2).

\section{1. 診断}

低位咬合，歯槽性の上顎前突，Skeletal Class I, 成 人男性症例。

\section{2. 治療方針}

下顎臼歯部にインプラントを埋入し，これを固定源に する上下顎の矯正治療を説明したが，患者は上顎のみの 矯正治療を希望した。 そのため，上顎前歯のレベリング とリトラクション，低位咬合に対する下顎部分床義歯の 調整によって審美性を改善した後, 固定性補綴物にて永 久保定することにした。

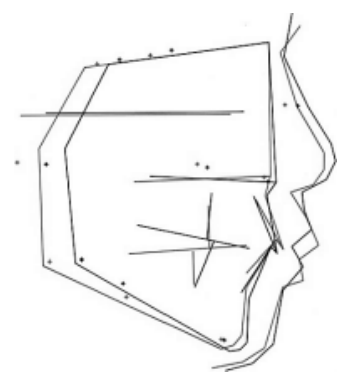

骨格系

SNA $81.05(81.82)$

SNB $77.14(78.07)$

ANB $\quad 3.91$ (3.75)

GZN $95.52(92.38)$

SN-MP 32.76 (37.57)

NB to Pog .05 (.45)

図 2 Profilogram before treatment 術前プロフィログラム 

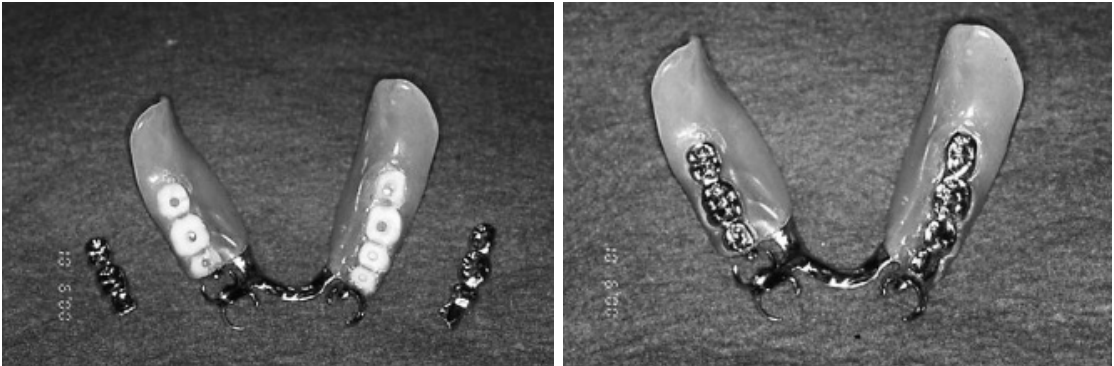

図 3 Lower removable partial denture using cast metal tooth 鋳造金属歯を応用した下顎部分床義歯

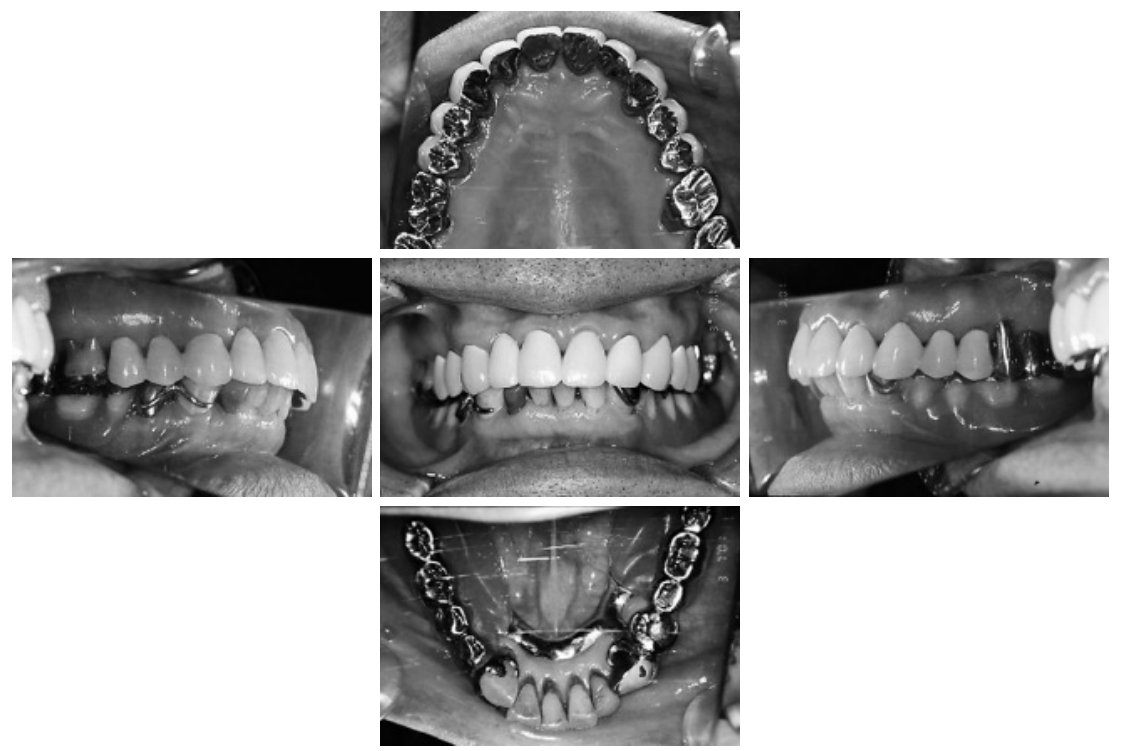

図 4 Intraoral views after treatment of upper fixed prosthesis 上顎ブリッジ装着後口腔内写真

\section{III，治療内容と経過}

治療方針について説明し，同意を得た１1月 2 日ま で(5) 4 (3) 2 (1)|(1)(2)(4)(5)プロビジョナルレスト レーションおよび下顎旧義歯の調整を行った。 11 月 9 日に下顎部分床義歯製作のための印象採得，16 日に咬 合採得，12月 7 日に下顎新義歯を装着した。 2000 年 1 月 20 日に矯正装置を装着し，プロビジョナルレスト レーションの連結部分を切断，調整した，矯正科にてレ ベリングと前歯のリトラクション後, 9 月 1 日に再度 (5) 4 (3)2 (1)|(1)(2)(4)(5)のプロビジョナルレストレー ションを装着し，歯冠形態と咬合関係の改善を行った。 顎関節には特に異常は認めなかった. 9 月 26 日に $\overline{76}$ $5 \mid 4567$ 部分床義歯咬合面改造のため印象，咬合採 得を行い，10月 6 日に精緻な咬合面形態と適度な耐摩
耗性を求め，金銀パラジウム合金製鋳造金属歯を下顎部 分床義歯に接着した(図 3). 12 月 5 日に(5) 4 (3) 2 (1)|(1) (2)(3)(4)ブリッジの形成，印象を行い，8日に咬合採 得を行った。20日にフレームワークを試適し，2001 年 1 月 16 日に硬質レジン前装クラウンによる(5) 4 (3) 2 (1)|(1)(2)(3)(5)ブリッジを永久保定装置として装着し た。 3 月 7 日，永久保定装置の咬合調整とブラッシン グ指導を行った（図 4).

永久保定装置を装着して約 10 力月後の 11 月 12 日 に下顎部分床義歯の右舌側床辺縁が破折し修理を行つ た. 永久保定装置装着後, 3 力月ごとの経過観察を行い, 2004 年 8 月 19 日現在で 3 年 7 カ月が経過した（図 5)。歯周組織検査のプロービングで 1 から出血を認め たため, 残存歯のスケーリング，ルートプレーニングを 行った. 

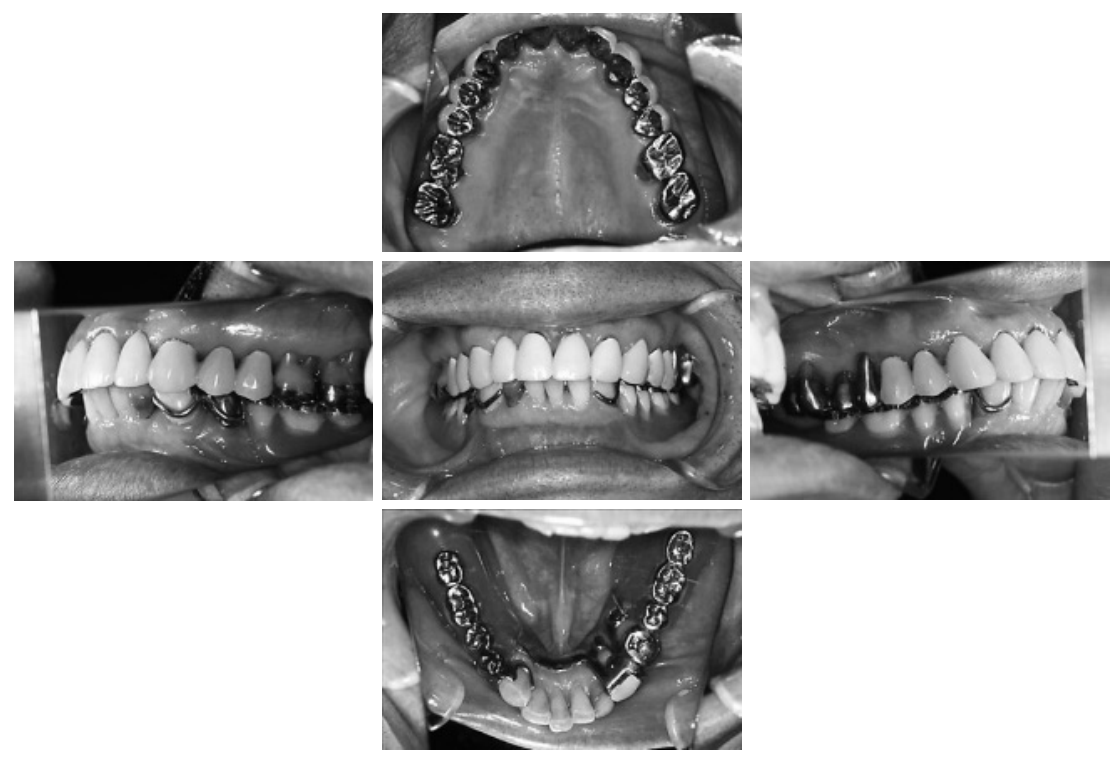

図 5 Intraoral views at three years and seven months after treatment 術後 3 年 7 力月経過時口腔内写真

\section{IV. 考 察}

患者は以前から保存科で歯周治療を中心とした治療を 受けていたが, 審美性の改善には至らなかった. 保存科, 矯正科, 補綴科それぞれ単独では治療に限界があり主訴 を改善することが困難な場合がある ${ }^{2)}$. しかし今回，矯 正科と補綴科の双方で協力しあい治療方針を決定するこ とで，明確な治療方針を患者に示すことができ，患者の 満足を得ることができた。インターディシプリナリー・・ アプローチは審美的治療を行うために有効であることが 確認され，補経医の主導で行われることが重要と思われ る.

\section{V. 結 論}

上顎前突による審美障害症例に対して矯正, 補経によ
るインターデイシプリナリー・アプローチを用いること で審美的，機能的にも良好な結果が得られた。

\section{文献}

1）福島俊士, 平井敏博, 古屋良一. 臨床咬合学. 東京 : 医 歯薬出版 ; 1995, 122-124.

2）諏訪裕彦，松原秀幸，諏訪富彦。下顎両側性大兒歯欠損 を伴う機能性反対咬合の審美的改善にインプラントを固 定源とした矯正治療を併用した 1 治験例。歯科審美（日 本歯科審美学会) 2002; 1:9-17.

著者連絡先: 國安 宏哉

T080-0019

北海道帯広市西 9 条南 28 丁目 24-3

Tel: $0155-49-4618$

Fax: 0155-49-4619

E-mail: kunident@fl.octv.ne.jp 